\title{
Assessment of the risk of exposure to cadmium and lead as a result of the consumption of coffee infusions
}

\author{
Anna Winiarska-Mieczan ${ }^{1} \cdot$ Katarzyna Kwiatkowska $^{1} \cdot$ Małgorzata Kwiecień $^{1} \cdot$ Ewa Zaricka $^{2}$
}

Received: 8 July 2020 / Accepted: 5 August 2020 / Published online: 13 August 2020

(C) The Author(s) 2020

\begin{abstract}
The paper aimed to analyse the safety of drinking coffee by adult Poles in terms of $\mathrm{Pb}$ and $\mathrm{Cd}$ content. The degree to which $\mathrm{Cd}$ and $\mathrm{Pb}$ passed from coffee grounds into the coffee infusion was also examined. Twenty-three samples of natural coffee were examined. The content of metals was determined using the ICP method. On average, dry coffee contained ca. $0.004 \mu \mathrm{g} \mathrm{Cd}$ and $0.05 \mu \mathrm{g} \mathrm{Pb}$ per $1 \mathrm{~g}$, and $95.5 \% \mathrm{Cd}$ and $94 \% \mathrm{~Pb}$ passed into the infusion. Drinking coffee supplies these metals in the amount of less than $2 \%$ TWI (tolerable weekly intake) for Cd and BMDL (benchmark dose lower confidence limit) for $\mathrm{Pb}$. In the presented studies, the values of CDI (chronic daily intake), THQ (target hazard quotient) and HI (hazard index) indicators were lower than 1 , which means that the risk of developing diseases connected with chronic exposure to $\mathrm{Cd}$ and $\mathrm{Pb}$ consumed with coffee must be evaluated as very low. The content of $\mathrm{Cd}$ and $\mathrm{Pb}$ in the analysed coffee infusions was very low, so drinking coffee does not pose a risk for consumers in terms of the content of these metals. However, it must be remembered that no threshold limits for toxic metal consumption exist because these metals accumulate in the body for a long time. The studies presented here also showed a low $(r=0.26)$ but still a positive correlation between the content of $\mathrm{Pb}$ in coffee and the degree $(\%)$ to which $\mathrm{Pb}$ passed into the infusion. This problem should be thoroughly investigated.
\end{abstract}

Keywords Coffee infusions $\cdot$ Cadmium $\cdot$ Lead $\cdot$ Risk assessment

\section{Introduction}

Coffee, next to tea, is one of the most popular drinks in the world [1]. It is a source of antioxidants including caffeine, phenolic compounds and diterpenes. Results of studies suggest that drinking coffee can increase the level of glutathione and improve the protection of the body against DNA damage, in particular, if consumed regularly [1]. It was demonstrated that drinking coffee decreased the risk of developing breast cancer, prostate and colorectal cancer, which is attributed to the presence of antioxidants $[2,3]$. It is also suggested that drinking coffee decreases the risk of developing chronic diseases such as type 2 diabetes and Parkinson's [4, 5]. According to surveys, $95.2 \%$ of adult Poles drink coffee

Anna Winiarska-Mieczan

anna.mieczan@up.lublin.pl

1 Department of Bromatology and Food Physiology, University of Life Sciences in Lublin, Akademicka 13, 20-950 Lublin, Poland

2 State Scientific-Research Control Institute of Veterinary Medical Products and Feed Additives, Lviv, Ukraine compared with $61 \%$ of Italians and about $40 \%$ of Spaniards $[6,7]$. Statistically, in 2017 in Poland, the consumption of coffee amounted to $2.16 \mathrm{~kg}$ per person [8]. In Poland, the most popular type of coffee is non-instant coffee (ground and grained). This is a choice of more than $50 \%$ of consumers, preceding instant coffee and coffee mixes [6]. Most often, Poles drink 1-3 cups of coffee a day $[9,10]$. However, one should not drink more than 5 cups $(1$ cup $=150 \mathrm{ml}=80 \mathrm{mg}$ caffeine) a day due to its possible negative effect on the cardiovascular system (increased LDL-chol and total cholesterol levels due to diterpenoid alcohols), problems falling asleep (caffeine), pregnancy (caffeine intake of $>300 \mathrm{mg}$ per day proved negative effect on the duration of pregnancy and weight at birth) and increased secretion of gastric acid and bile, which exacerbates peptic ulcer disease and hyperacidity [1, 11-13].

Apart from antioxidants and other bioactive compounds, coffee contains carbohydrates, lipids, nitrogen compounds, vitamins and minerals, including toxic elements such as cadmium $(\mathrm{Cd})$ and lead $(\mathrm{Pb})[12,14,15]$. The presence of toxic metals in food is a global problem. Their primary source for humans is the food of plant origin [16, 17]. Although, according to available literature and own studies, the content of $\mathrm{Cd}$ 
and $\mathrm{Pb}$ in food products normally does not exceed acceptable standard levels, due to the fact that these metals are capable of accumulating in tissues and have a long half-life: 5-30 years for $\mathrm{Cd}$ and from 30 days (in soft tissue) to 10 years (in bones) for $\mathrm{Pb}$ [18], their regular supply, even in small amounts, is dangerous. These metals display mutagenic, teratogenic, carcinogenic and embryotoxic effects [19]. In 2012, EFSA reduced the tolerable intake level for $\mathrm{Cd}$ and $\mathrm{Pb}$. The TWI (tolerable weekly intake) for $\mathrm{Cd}$ was determined at the level of $2.5 \mu \mathrm{g} \mathrm{kg}^{-1}$ of body weight per week [16], whereas the BMDL (benchmark dose lower confidence limit) for $\mathrm{Pb}$ was BMDL $_{01}-10.5 \mu \mathrm{g} \mathrm{kg}^{-1}$ of body weight per week - and BMDL $_{10}-4.4 \mu \mathrm{g} \mathrm{kg}^{-1}$ of body weight per week [17]. The paper aimed at analysing the safety of drinking coffee by adult Poles in terms of $\mathrm{Pb}$ and $\mathrm{Cd}$ content. The degree to which $\mathrm{Cd}$ and $\mathrm{Pb}$ passed from coffee grounds into the coffee infusion was also examined. The presented results are a part of the project aiming to estimate the intake of minerals (toxic and essential) in the Polish population.

\section{Material and methods}

\section{Study material}

Twenty-three samples of natural coffee were examined (Table 1). The products were purchased in August 2017 from local groceries, still within their shelf life. Before the analyses, the coffee was stored in original, tightly sealed packages at room temperature.

\section{Preparation of samples for analyses}

Grained coffee was ground in a laboratory grinder with plastic blades. Ground coffee was mixed by hand. Coffee infusions were prepared as follows: $6 \mathrm{~g}$ of ground coffee was poured with $100 \mathrm{ml}$ of drinking water with a temperature of 95-100 ${ }^{\circ} \mathrm{C}$; after $10 \mathrm{~min}$, the solutions were drained through the Whatman drain. The resulting coffee grounds were dried in a drier at a temperature of $65^{\circ} \mathrm{C}$ for $24 \mathrm{~h}$. Afterwards, they
Table 1 Characteristic of the analysed products

\begin{tabular}{|c|c|c|c|c|c|c|c|}
\hline & $\begin{array}{l}\text { Coffee } \\
\text { form }\end{array}$ & $\begin{array}{l}\text { Coffee } \\
\text { varieties }\end{array}$ & Trademark & $\begin{array}{l}\text { Size of } \\
\text { package, } g\end{array}$ & Annotation & Origin & Made in \\
\hline 1 & Beans & $\begin{array}{c}\text { Arabica }+ \\
\text { Robusta }\end{array}$ & A & 1000 & & $\begin{array}{c}\text { South America, } \\
\text { Asia, Africa }\end{array}$ & Poland \\
\hline 2 & Beans & No data & B-1 & 1000 & & No data & Poland \\
\hline 3 & Ground & No data & B-2 & 250 & & No data & Poland \\
\hline 4 & Ground & Robusta & $\mathrm{C}$ & 400 & & India & Poland \\
\hline 5 & Beans & Arabica & D-1 & 500 & & Brazil & Holland \\
\hline 6 & Beans & $\begin{array}{c}\text { Arabica }+ \\
\quad \text { Robusta }\end{array}$ & D-2 & 1000 & & No data & Holland \\
\hline 7 & Ground & Arabica & D-1 & 500 & & Columbia & Holland \\
\hline 8 & Ground & Arabica & D-3 & 500 & & Brazil & Holland \\
\hline 9 & Ground & Arabica & G-1 & 250 & $\begin{array}{c}\text { Bio, Fair } \\
\text { Trade }\end{array}$ & $\begin{array}{l}\text { Papua New Guinea, } \\
\text { Peru, Mexico }\end{array}$ & Italy \\
\hline 10 & Ground & Arabica & G-2 & 250 & & Brazil & Italy \\
\hline 11 & Beans & $\begin{array}{l}\text { Arabica }+ \\
\text { Robusta }\end{array}$ & G-3 & 1000 & & $\begin{array}{l}\text { South America, } \\
\text { Indonesia }\end{array}$ & Italy \\
\hline 12 & Ground & $\begin{array}{l}\text { Arabica }+ \\
\text { Robusta }\end{array}$ & I & 250 & & $\begin{array}{l}\text { South America, } \\
\text { Indonesia }\end{array}$ & Germany \\
\hline 13 & Ground & Robusta & $\mathrm{J}-1$ & 500 & & Vietnam & Germany \\
\hline 14 & Ground & Robusta & $\mathrm{J}-2$ & 250 & & India & Germany \\
\hline 15 & Ground & Robusta & $\mathrm{J}-2$ & 100 & & India & Germany \\
\hline 16 & Ground & Arabica & $\mathrm{J}-2$ & 500 & & Brazil & Germany \\
\hline 17 & Beans & Arabica & $\mathrm{J}-3$ & 1000 & Fair Trade & $\begin{array}{c}\text { Bolivia, Peru, } \\
\text { Ecuador, } \\
\text { Nicaragua }\end{array}$ & Germany \\
\hline 18 & Ground & Arabica & $\mathrm{K}-1$ & 500 & & Brazil & Germany \\
\hline 19 & Ground & Arabica & $\mathrm{K}-2$ & 500 & & South America & Germany \\
\hline 20 & Beans & Arabica & $\mathrm{K}-3$ & 500 & & South America & Germany \\
\hline 21 & Beans & $\begin{array}{c}\text { Arabica }+ \\
\quad \text { Robusta }\end{array}$ & $\mathrm{K}-4$ & 500 & & $\begin{array}{l}\text { South America, } \\
\text { Indonesia }\end{array}$ & Germany \\
\hline 22 & Ground & Arabica & $\mathrm{L}$ & 500 & & Brazil & Germany \\
\hline 23 & Ground & Arabica & M & 227 & Fair Trade & Peru, Nicaragua & England \\
\hline
\end{tabular}


were pulverised in a laboratory grinder with plastic blades. The analyses covered both fresh ground coffee and coffee grounds remaining after coffee brewing.

\section{Chemical analyses}

The analysed material was manually mixed. Samples weighing ca. $3 \mathrm{~g}$ were weighed in 3 replications into previously heat sterilised china crucibles and then subjected to dry mineralisation in a muffle furnace at a temperature of $450{ }^{\circ} \mathrm{C}$. The oxidant was hydrogen peroxide. The mineralisate was dissolved in $10 \mathrm{ml}$ of $1 \mathrm{M} \mathrm{HNO}_{3}[20,21]$. The content of cadmium and lead was determined using ICP (inductively coupled plasma mass spectrometry) in a Varian 820 MS spectrometer (Varian, Melbourne, Australia). The parameters for determination and control of correct analyses were included in Table 2. The calibration curve was drawn using the models:

Cd: standard characterised by $99.999 \%$ purity used to prepare solutions with the concentration of $0.2 ; 0.4 ; 1$; $2 ; 4 ; 10 \mu \mathrm{g}$ of $\mathrm{Cd} \mathrm{L}^{-1}$; the solutions were prepared in $1 \%$ ultra-pure nitric acid $(\mathrm{V})$.
$\mathrm{Pb}$ : standard characterised by $99.999 \%$ purity used to prepare solutions with the concentration of $0.1 ; 0.2 ; 0.5$; $1 ; 2 ; 5 \mu \mathrm{g}$ of $\mathrm{Pb} \mathrm{L}^{-1}$; the solutions were prepared in $1 \%$ ultra-pure nitric acid $(\mathrm{V})$.

Each chemical analyses was repeated 3 times. The accuracy of determination was verified using a blind test $(1 \mathrm{M}$ $\mathrm{HNO}_{3}$ ) and two certified reference materials (CRM): INCTTL-1 Tea leaves (containing $0.030 \mathrm{mg} \mathrm{Cd}$ and $1.78 \mathrm{mg} \mathrm{Pb}$ per $1 \mathrm{~kg}$ ) and INCT-MPH-2 Mixed Polish herbs (containing $0.199 \mathrm{mg} \mathrm{Cd}$ and $2.16 \mathrm{mg} \mathrm{Pb}$ per $1 \mathrm{~kg}$ ).

\section{Reagents and reference materials}

Hydrogen peroxide $\mathrm{H}_{2} \mathrm{O}_{2}\left(30 \%\right.$ pure) and nitric acid $\mathrm{HNO}_{3}$ (65\% ultra-pure) were purchased from POCH S.A. (Poland). Deionised water used for dilution was made in our laboratory (Hydrolab Poland, Gdańsk). The $\mathrm{Cd}$ and $\mathrm{Pb}$ standards were purchased from Merck (Germany). Certified reference materials INCT-TL-1 and INCT-MPH-2 were obtained from the Institute of Nuclear Chemistry and Technology (Warsaw, Poland).
Table 2 Measurement parameters and validation data for the determination of $\mathrm{Cd}$ and $\mathrm{Pb}$ levels by ICP-MS

\begin{tabular}{|c|c|c|}
\hline & $\mathrm{Cd}$ & $\mathrm{Pb}$ \\
\hline Mass monitored & 114 & $206 ; 207 ; 208$ \\
\hline Plasma gas & Argon & Argon \\
\hline Plasma gas flow, $\mathrm{L} \mathrm{min}-1$ & 18 & 18 \\
\hline Nebuliser gas flow, $\mathrm{L} \mathrm{min}^{-1}$ & 1 & 1 \\
\hline Auxiliary gas flow, $\mathrm{L} \mathrm{min}^{-1}$ & 1.70 & 1.70 \\
\hline Sampling depth, mm & 5 & 5 \\
\hline RF power, $\mathrm{kW}$ & 1.37 & 1.37 \\
\hline Limit of detection LOD, $\mu \mathrm{g} \mathrm{kg}^{-1}$ & 0.004 & 0.005 \\
\hline $\begin{array}{l}\text { Limit of quantification LOQ, } \mu \mathrm{g} \\
\mathrm{kg}^{-1}\end{array}$ & 0.010 & 0.030 \\
\hline \multicolumn{3}{|l|}{ Quality control } \\
\hline Blank sample & $1 \mathrm{M} \mathrm{HNO}_{3}$ & $1 \mathrm{M} \mathrm{HNO}_{3}$ \\
\hline Certified reference material (1) & INCT-TL-1 (tea leaves) & INCT-TL-1 (tea leaves) \\
\hline Certified reference material (2) & $\begin{array}{l}\text { INCT-MPH-2 (mixed Polish } \\
\text { herbs) }\end{array}$ & $\begin{array}{l}\text { INCT-MPH-2 (mixed Polish } \\
\text { herbs) }\end{array}$ \\
\hline \multicolumn{3}{|c|}{ Certified element concentration in CRM 1} \\
\hline Certified, $\mathrm{mg} \mathrm{kg}^{-1}$ & 0.030 & 1.78 \\
\hline Observed, $\mathrm{mg} \mathrm{kg}^{-1}$ & 0.029 & 1.76 \\
\hline Recovery rate, $\%$ & 98 & 99 \\
\hline \multicolumn{3}{|c|}{ Certified element concentration in CRM 2} \\
\hline Certified, $\mathrm{mg} \mathrm{kg}^{-1}$ & 0.199 & 2.16 \\
\hline Observed, $\mathrm{mg} \mathrm{kg}^{-1}$ & 0.189 & 2.22 \\
\hline Recovery rate, $\%$ & 95 & 103 \\
\hline Precision, $\%$ & 6.04 & 6.07 \\
\hline Replicates & 3 & 3 \\
\hline
\end{tabular}




\section{Calculations}

Based on the difference in the content of $\mathrm{Cd}$ and $\mathrm{Pb}$ in coffee grounds, the degree (\%) to which those metals passed into the infusion was calculated prior to after coffee brewing.

The safety of drinking coffee for adult Poles was estimated on the grounds of (1) calculation of the percentage of $\mathrm{Cd}$ and $\mathrm{Pb}$ intake in comparison with the acceptable level proposed by EFSA [16, 17], (2) calculation of parameters describing the risk of development of cancer and (3) calculation of parameters describing the risk of development of non-carcinogenic diseases. Three consumption patterns were taken into account in the calculations: 1 cup, 2 cups or 3 cups a day for 365 days in a year because such amounts of coffee in Poland are drunk by ca. $80 \%$ of coffee drinkers $[9,10]$.

\section{(1) Percent of tolerable dose:}

Estimated weekly intake (EWI) of $\mathrm{Cd}$ and $\mathrm{Pb}$ was calculated according to the formula [22]:

$E W I=\frac{M W C \times \text { metal level }}{100}$

where MWC is the mean weekly consumption of coffee (one, two or three cups).

Tolerable weekly intake \% (TWI) was calculated according to the formula [22]:

$\% T W I=\frac{E W I_{C d} \times 100}{T W I}$

The value adopted for TWI was $2.5 \mu \mathrm{g} \mathrm{Cd} \mathrm{kg}{ }^{-1}$ of body weight per week [16].

Benchmark dose lower confidence limit \% (BMDL) was calculated according to the formula [22]:

$\% B M D L=\frac{E W I_{P b} \times 100}{B M D L}$

The value adopted for BMDL: two values suggested by the European Food Safety Authority (EFSA) were calculated per 1 week: $\mathrm{BMDL}_{01}-10.5 \mu \mathrm{g} \mathrm{Pb} \mathrm{kg}{ }^{-1}$ of body weight per week - and $\mathrm{BMDL}_{10}-4.4 \mu \mathrm{g} \mathrm{Pb} \mathrm{kg}^{-1}$ of body weight per week [17].

The mean body weight was assumed as $70 \mathrm{~kg}$.

\section{(2) Cancer risks parameters}

Chronic daily intake (CDI) of $\mathrm{Cd}$ or $\mathrm{Pb}$ was calculated according to the formula [23, 24]:

$\mathrm{CDI}=\frac{\mathrm{EDI} \times \mathrm{EFr} \times \mathrm{ED}_{\text {tot }}}{\text { body weight } \times \mathrm{AT}}$

where EDI is the estimated daily intake of $\mathrm{Cd}$ and $\mathrm{Pb}$, calculated on the basis of the mean weekly consumption of coffee (one, two or three cups) and mean level of $\mathrm{Cd}$ and $\mathrm{Pb}$; $\mathrm{EFr}$ is the days of exposure frequency ( 365 per year); $\mathrm{ED}_{\mathrm{tot}}$ is the exposure duration (years) - since in Poland regular coffee drinkers are adults only, it was assumed that the time of exposure was calculated from 18 to 74 years of age (74 yearsaverage life span in Poland), which is 56 years; AT is the period of exposure (365 per year).

CSF is a cancer slope factor which is the risk produced by a lifetime average dose of $1 \mathrm{mg} \mathrm{kg}^{-1} \mathrm{BW}$ per day and is contaminant specific.

\section{(3) Non-carcinogenic risks parameters}

Target hazard quotient (THQ) was calculated according to the formula [23]:

$\mathrm{THQ}=\mathrm{CDI} / \mathrm{RfD}$

where $\mathrm{CDI}$ is the chronic daily intake of $\mathrm{Cd}$ or $\mathrm{Pb}$.

$\mathrm{RfD}$ (reference dose) for $\mathrm{Cd}$ is $1 \mu \mathrm{g} \mathrm{kg}^{-1}$ of body weight per day, whereas, for $\mathrm{Pb}$, it is $3.5 \mu \mathrm{g} \mathrm{kg}^{-1}$ of body weight per day [25].

When THQ is higher than 1, it is assumed that there is a significant risk of developing negative effects on health resulting from chronic exposure to $\mathrm{Cd}$ and/or $\mathrm{Pb}$ [26].

Hazard index (HI) was calculated according to the formula [23]:

$\mathrm{HI}=\mathrm{THQ}_{\mathrm{Cd}}+\mathrm{THQ}_{\mathrm{Pb}}$

\section{Statistical analysis}

The mean content of $\mathrm{Cd}$ and $\mathrm{Pb}$ was calculated for each sample (three weighing replications $\times 3$ replications of chemical analysis). A statistical analysis of the results (average value, minimum and maximum value, standard deviation, median, 75 and 25 percentile) was carried out using Statistica 13.1 software. Statistically significant differences $(P<0.05)$ were computed by single factor analysis of variance (ANOVA), using the Duncan test. The correlation between the content of $\mathrm{Cd}$ and $\mathrm{Pb}$ in coffee and the degree (\%) to which they passed into the infusion was calculated using Pearson's method (Statistica 6.0 software).

\section{Results}

\section{Content of $\mathrm{Cd}$ and $\mathrm{Pb}$ in coffee}

Dry coffee prior to brewing contained from 1.204 to $10.33 \mu \mathrm{g}$ $\mathrm{Cd}$ per $1 \mathrm{~kg}$ (Tables 3 and 4). The mean content of $\mathrm{Cd}$ in the analysed samples was $3.784 \mu \mathrm{g}( \pm 2.464)$ per $1 \mathrm{~kg}$. Coffee 
grounds contained from < LOQ to $0.698 \mu \mathrm{g} \mathrm{Cd}$ per $1 \mathrm{~kg}$; in $35 \%$ of samples, the level of Cd was lower than determinable with the applied method ( $\mathrm{LOQ}=0.01 \mu \mathrm{g} \mathrm{kg}^{-1}$ ). About 79 to $100 \%$ (on average $95.5 \%$ ) of $\mathrm{Cd}$ present in the output material passed into the infusion; the infusion contained, on average $3.613 \mu \mathrm{g} \mathrm{kg}^{-1}$ (range $1.2-10.33 \mu \mathrm{g}$ ). A very low positive correlation $r=0.15$ was identified between the content of $\mathrm{Cd}$ in coffee and the degree (\%) to which $\mathrm{Cd}$ passed into the infusion (Fig. 1a). On average, dry coffee prior to brewing contained ca. $49.6 \mu \mathrm{g} \mathrm{kg}^{-1} \mathrm{~Pb}$ (range 21.22-80.06 $\mu \mathrm{g} \mathrm{kg}^{-1}$ ), whereas coffee grounds < LOQ $-10.2 \mu \mathrm{g} \mathrm{kg}^{-1}$. In $17 \%$ of coffee ground samples, the level of $\mathrm{Pb}$ was lower than determinable using the analytical method applied (LOQ $=0.03 \mu \mathrm{g}$ $\mathrm{kg}^{-1}$ ). From nearly 79 to $100 \%$ (on average $94 \%$ ) of $\mathrm{Pb}$ passed into the infusion, the infusion contained, on average, $46.86 \mu \mathrm{g}$ $\mathrm{kg}^{-1}$ (range 16.66-80.06 $\mu \mathrm{g}$ ). A low positive correlation $r=$ 0.26 was identified between the content of $\mathrm{Pb}$ in coffee and the degree (\%) to which $\mathrm{Pb}$ passed into the infusion (Fig. 1b).

\section{Coffee drinking safety}

Data concerning the estimated safety of drinking coffee infusions, taking into account three consumption patterns $(1,2$ or 3 cups of coffee a day), is presented in Table 5 .

Pattern 1: 1 cup of coffee a day The estimated weekly intake (EWI) of Cd with coffee infusion is $0.156 \mu \mathrm{g}$, which accounts for about $0.09 \%$ TWI. The value of $\mathrm{CDI}_{\mathrm{Cd}}$ and $\mathrm{THQ}_{\mathrm{Cd}}$ indicators is identical and it amounts to 0.022. The estimated weekly intake of $\mathrm{Pb}$ is $1.968 \mu \mathrm{g}$, which corresponds to ca. $0.27 \% \mathrm{BMDL}_{01}$ and ca. $0.64 \% \mathrm{BMDL}_{10}$. The value of $\mathrm{CDI}_{\mathrm{Pb}}=0.281$, whereas that of $\mathrm{THQ}_{\mathrm{Pb}}=0.08$. The HI risk factor $(\mathrm{Cd}+\mathrm{Pb})$ is 0.103 .

Pattern 2: 2 cups of coffee a day EWI of Cd with coffee is $0.312 \mu \mathrm{g}$, which accounts for $0.18 \%$ of TWI. The value of $\mathrm{CDI}_{\mathrm{Cd}}$ and $\mathrm{THQ}_{\mathrm{Cd}}$ indicators is 0.045 each. EWI of $\mathrm{Pb}$ is ca.
Table 3 Content of $\mathrm{Cd}$ and $\mathrm{Pb}$ in dry ground coffee (before brewing), dregs and infusions ( $n=$ 23), $\mu \mathrm{g} \mathrm{kg}^{-1}$

\begin{tabular}{|c|c|c|c|c|c|c|c|c|}
\hline & \multicolumn{2}{|l|}{ Dry coffee } & \multicolumn{2}{|l|}{ Dregs } & \multicolumn{2}{|l|}{ Infusions } & \multicolumn{2}{|c|}{$\begin{array}{l}\text { Leaching percentages of } \mathrm{Cd} \\
\text { and } \mathrm{Pb}\end{array}$} \\
\hline & $\mathrm{Cd}$ & $\mathrm{Pb}$ & $\mathrm{Cd}$ & $\mathrm{Pb}$ & $\mathrm{Cd}$ & $\mathrm{Pb}$ & $\mathrm{Cd}$ & $\mathrm{Pb}$ \\
\hline 1 & $5.041^{\mathrm{E}}$ & $73.37^{\mathrm{F}}$ & $0.600^{\mathrm{F}}$ & $10.20^{\mathrm{I}}$ & $4.443^{\mathrm{D}}$ & $63.17^{\mathrm{F}}$ & $88^{\mathrm{B}}$ & $87^{\mathrm{A}}$ \\
\hline 2 & $10.33^{\mathrm{I}}$ & $74.37^{\mathrm{F}}$ & $<\mathrm{LOQ}^{\mathrm{A}}$ & $6.280^{\mathrm{H}}$ & $10.33^{\mathrm{H}}$ & $68.09^{\mathrm{F}}$ & $100^{\mathrm{C}}$ & $92^{\mathrm{A}, \mathrm{B}}$ \\
\hline 3 & $1.204^{\mathrm{A}}$ & $34.84^{\mathrm{B}}$ & $<\mathrm{LOQ}^{\mathrm{A}}$ & $5.134^{\mathrm{G}}$ & $1.203^{\mathrm{A}}$ & $29.71^{\mathrm{C}}$ & $100^{\mathrm{C}}$ & $85^{\mathrm{A}}$ \\
\hline 4 & $3.991^{\mathrm{D}}$ & $38.04^{\mathrm{B}, \mathrm{C}}$ & $<\mathrm{LOQ}^{\mathrm{A}}$ & $2.143^{C}$ & $3.990^{\mathrm{D}}$ & $36.89^{\mathrm{C}, \mathrm{D}}$ & $100^{\mathrm{C}}$ & $95^{\mathrm{B}}$ \\
\hline 5 & $8.883^{\mathrm{H}}$ & $43.47^{\mathrm{C}}$ & $<\mathrm{LOQ}^{\mathrm{A}}$ & $1.087^{\mathrm{B}}$ & $8.882^{\mathrm{G}}$ & $42.38^{\mathrm{D}}$ & $100^{\mathrm{C}}$ & $97^{\mathrm{B}}$ \\
\hline 6 & $3.289^{\mathrm{C}}$ & $80.06^{\mathrm{G}}$ & $0.702^{\mathrm{G}}$ & $<\mathrm{LOQ}^{\mathrm{A}}$ & $2.593^{\mathrm{B}, \mathrm{C}}$ & $80.06^{\mathrm{G}}$ & $78^{\mathrm{A}}$ & $100^{\mathrm{B}}$ \\
\hline 7 & $1.502^{\mathrm{A}}$ & $44.21^{\mathrm{C}}$ & $<\mathrm{LOQ}^{\mathrm{A}}$ & $1.120^{\mathrm{B}}$ & $1.502^{\mathrm{A}, \mathrm{B}}$ & $43.09^{\mathrm{D}}$ & $100^{\mathrm{C}}$ & $97^{\mathrm{B}}$ \\
\hline 8 & $2.100^{\mathrm{B}}$ & $33.87^{\mathrm{B}, \mathrm{C}}$ & $0.100^{\mathrm{B}}$ & $2.549^{\mathrm{C}}$ & $2.000^{\mathrm{B}}$ & $31.32^{\mathrm{C}}$ & $95^{\mathrm{B}, \mathrm{C}}$ & $92^{\mathrm{A}, \mathrm{B}}$ \\
\hline 9 & $3.411^{\mathrm{C}, \mathrm{D}}$ & $58.12^{\mathrm{D}, \mathrm{E}}$ & $0.313^{\mathrm{D}}$ & $<\mathrm{LOQ}^{\mathrm{A}}$ & $3.100^{\mathrm{C}}$ & $58.12^{\mathrm{E}, \mathrm{F}}$ & $91^{\mathrm{B}, \mathrm{C}}$ & $100^{\mathrm{B}}$ \\
\hline 10 & $2.204^{\mathrm{B}}$ & $61.35^{\mathrm{E}}$ & $0.122^{\mathrm{B}}$ & $1.223^{\mathrm{B}}$ & $2.084^{\mathrm{B}}$ & $60.13^{\mathrm{F}}$ & $95^{\mathrm{B}, \mathrm{C}}$ & $98^{\mathrm{B}}$ \\
\hline 11 & $1.273^{\mathrm{A}}$ & $55.41^{\mathrm{D}}$ & $<\mathrm{LOQ}^{\mathrm{A}}$ & $3.320^{\mathrm{E}}$ & $1.272^{\mathrm{A}}$ & $52.09^{\mathrm{E}}$ & $100^{\mathrm{C}}$ & $94^{\mathrm{A}, \mathrm{B}}$ \\
\hline 12 & $2.100^{\mathrm{B}}$ & $61.35^{\mathrm{E}}$ & $<\mathrm{LOQ}^{\mathrm{A}}$ & $4.581^{\mathrm{F}}$ & $1.994^{\mathrm{B}}$ & $56.77^{\mathrm{E}, \mathrm{F}}$ & $95^{\mathrm{B}, \mathrm{C}}$ & $93^{\mathrm{A}, \mathrm{B}}$ \\
\hline 13 & $3.122^{\mathrm{C}}$ & $54.36^{\mathrm{D}}$ & $0.189^{\mathrm{C}}$ & $1.250^{\mathrm{B}}$ & $2.932^{\mathrm{C}}$ & $53.11^{\mathrm{E}}$ & $94^{\mathrm{B}, \mathrm{C}}$ & $98^{\mathrm{B}}$ \\
\hline 14 & $7.703^{\mathrm{G}}$ & $33.35^{\mathrm{B}}$ & $0.133^{\mathrm{B}}$ & $<\mathrm{LOQ}^{\mathrm{A}}$ & $7.573^{\mathrm{F}}$ & $33.35^{\mathrm{C}}$ & $98^{\mathrm{B}, \mathrm{C}}$ & $100^{\mathrm{B}}$ \\
\hline 15 & $6.111^{\mathrm{F}}$ & $44.36^{\mathrm{C}}$ & $<\mathrm{LOQ}^{\mathrm{A}}$ & $3.561^{\mathrm{D}}$ & $6.110^{\mathrm{E}}$ & $40.80^{\mathrm{D}}$ & $100^{\mathrm{C}}$ & $92^{\mathrm{A}, \mathrm{B}}$ \\
\hline 16 & $1.489^{\mathrm{A}}$ & $55.36^{\mathrm{D}}$ & $0.100^{\mathrm{B}}$ & $3.210^{\mathrm{D}}$ & $1.389^{\mathrm{A}}$ & $52.15^{\mathrm{E}}$ & $93^{\mathrm{B}, \mathrm{C}}$ & $94^{\mathrm{A}, \mathrm{B}}$ \\
\hline 17 & $2.110^{\mathrm{B}}$ & $21.36^{\mathrm{A}}$ & $0.122^{\mathrm{B}}$ & $1.122^{\mathrm{B}}$ & $1.980^{\mathrm{B}}$ & $20.24^{\mathrm{B}, \mathrm{C}}$ & $95^{\mathrm{B}, \mathrm{C}}$ & $95^{\mathrm{A}, \mathrm{B}}$ \\
\hline 18 & $3.311^{\mathrm{C}}$ & $65.12^{\mathrm{E}}$ & $0.191^{\mathrm{C}}$ & $3.220^{\mathrm{D}}$ & $3.122^{\mathrm{C}}$ & $6.900^{\mathrm{A}}$ & $94^{\mathrm{B}, \mathrm{C}}$ & $95^{\mathrm{A}, \mathrm{B}}$ \\
\hline 19 & $4.089^{\mathrm{D}}$ & $21.22^{\mathrm{A}}$ & $0.210^{\mathrm{C}}$ & $4.558^{\mathrm{E}}$ & $3.881^{\mathrm{C}}$ & $16.66^{\mathrm{B}}$ & $95^{\mathrm{B}, \mathrm{C}}$ & $78^{\mathrm{A}}$ \\
\hline 20 & $2.210^{\mathrm{B}}$ & $35.48^{\mathrm{B}}$ & $<\operatorname{LOQ}^{\mathrm{A}}$ & $<\operatorname{LOQ}^{\mathrm{A}}$ & $2.200^{\mathrm{B}}$ & $35.48^{\mathrm{C}, \mathrm{D}}$ & $100^{\mathrm{C}}$ & $100^{\mathrm{B}}$ \\
\hline 21 & $3.401^{\mathrm{C}, \mathrm{D}}$ & $48.22^{\mathrm{C}}$ & $0.103^{\mathrm{B}}$ & $2.010^{\mathrm{C}}$ & $3.321^{\mathrm{C}}$ & $46.21^{\mathrm{D}, \mathrm{E}}$ & $97^{\mathrm{B}, \mathrm{C}}$ & $96^{\mathrm{B}}$ \\
\hline 22 & $5.824^{\mathrm{F}}$ & $63.22^{\mathrm{E}}$ & $0.222^{\mathrm{C}}$ & $2.011^{\mathrm{C}}$ & $5.602^{\mathrm{E}}$ & $61.21^{\mathrm{F}}$ & $97^{\mathrm{B}, \mathrm{C}}$ & $97^{\mathrm{B}}$ \\
\hline 23 & $4.350^{\mathrm{D}}$ & $38.95^{\mathrm{B}, \mathrm{C}}$ & $0.484^{\mathrm{E}}$ & $4.123^{\mathrm{F}}$ & $3.874^{\mathrm{C}}$ & $34.83^{\mathrm{C}}$ & $89^{\mathrm{B}}$ & $89^{\mathrm{A}, \mathrm{B}}$ \\
\hline
\end{tabular}

Average values for 3 replications

A, B Means with different superscripts in the same column differs significantly at $P<0.05$ by Duncan's test; LOQ $\mathrm{Cd}=0.010 \mu \mathrm{g} \mathrm{kg}^{-1} ;$ LOQ $\mathrm{Pb}=0.030 \mu \mathrm{g} \mathrm{kg}^{-1}$ 
Table 4 Results of coffee analysis $(n=23)$

\begin{tabular}{|c|c|c|c|c|}
\hline & Dry coffee & Dregs & Infusions & Leaching percentages of $\mathrm{Cd}$ and $\mathrm{Pb}$ \\
\hline \multicolumn{5}{|l|}{$\mathrm{Cd}, \mu \mathrm{g} \mathrm{kg}^{-1}$} \\
\hline Mean & 3.784 & 0.156 & 3.613 & 95.49 \\
\hline Maximum & 10.33 & 0.698 & 10.33 & 100.0 \\
\hline Minimum & 1.204 & $<\mathrm{LOQ}$ & 1.200 & 78.79 \\
\hline Median & 3.300 & 0.100 & 3.101 & 95.45 \\
\hline $\mathrm{SD}$ & 2.464 & 0.197 & 2.471 & 5.162 \\
\hline Variance analysis & 0.607 & 0.001 & 0.609 & 26.65 \\
\hline \multicolumn{5}{|l|}{ Percentile } \\
\hline $75 \%$ & 4.720 & 0.200 & 4.222 & 100.0 \\
\hline $25 \%$ & 2.100 & $<$ LOQ & 2.000 & 93.74 \\
\hline Percent of samples $<$ LOQ & $0 \%$ & $35 \%$ & & \\
\hline \multicolumn{5}{|l|}{$\mathrm{Pb}, \mu \mathrm{g} \mathrm{kg}^{-1}$} \\
\hline Mean & 49.59 & 2.726 & 46.86 & 94.07 \\
\hline Maximum & 80.06 & 10.20 & 80.06 & 100.0 \\
\hline Minimum & 21.22 & $<\mathrm{LOQ}$ & 16.66 & 78.51 \\
\hline Median & 48.22 & 2.143 & 46.21 & 94.76 \\
\hline $\mathrm{SD}$ & 16.27 & 2.412 & 15.85 & 5.332 \\
\hline Variance analysis & 26.47 & 5.819 & 25.16 & 28.43 \\
\hline \multicolumn{5}{|l|}{ Percentile } \\
\hline $75 \%$ & 61.35 & 3.840 & 59.12 & 97.60 \\
\hline $25 \%$ & 37.22 & 1.120 & 35.16 & 92.22 \\
\hline Percent of samples $<$ LOQ & $0 \%$ & $17 \%$ & & \\
\hline
\end{tabular}

Average values for samples, each in 3 replications; $S D$, standard deviation; $L O Q$, limit of quantitation; $\mathrm{LOQ} \mathrm{Cd}=$ $0.01 \mu \mathrm{g} \mathrm{kg}^{-1} ; \mathrm{LOQ} \mathrm{Pb}=0.03 \mu \mathrm{g} \mathrm{kg}^{-1}$

3.94, which corresponds to $0.54 \% \mathrm{BMDL}_{01}$ and nearly $1.3 \%$ $\mathrm{BMDL}_{10}$. The value of $\mathrm{CDI}_{\mathrm{Pb}}=0.56$, whereas $\mathrm{THQ}_{\mathrm{Pb}}=0.16$. The HI risk factor equals 0.205 .

Pattern 3: 3 cups of coffee a day EWI of Cd with infusion is less than $0.5 \mu \mathrm{g}$, which accounts for about $0.27 \%$ TWI. The values of $\mathrm{CDI}_{\mathrm{Cd}}$ and $\mathrm{THQ}_{\mathrm{Cd}}$ indicators are 0.067 each. EWI of $\mathrm{Pb}$ was equal to $5.715 \mu \mathrm{g}$, which corresponds to about $0.78 \% \mathrm{BMDL}_{01}$ and about $1.86 \% \mathrm{BMDL}_{10}$. The value of

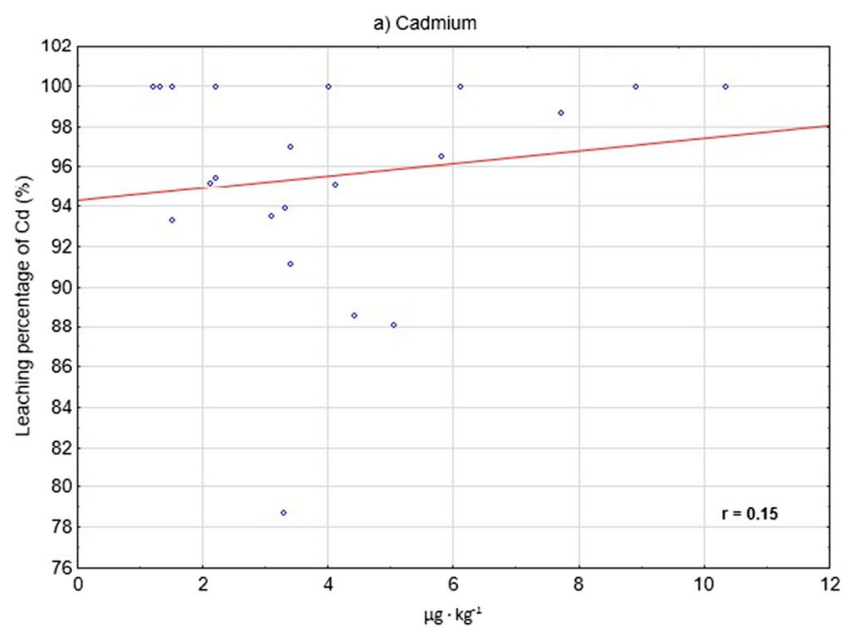

$\mathrm{CDI}_{\mathrm{Pb}}=816$, whereas $\mathrm{THQ}_{\mathrm{Pb}}=233$. The HI risk factor equals 0.3 .

\section{Discussion}

In the presented studies of this author, dry coffee contained on average nearly $3.8 \mu \mathrm{g} \mathrm{Cd}$ and ca. $50 \mu \mathrm{g} \mathrm{Pb}$ per $1 \mathrm{~kg}$ of the natural product, which accounts for ca. $0.004 \mu \mathrm{g} \mathrm{Cd}$ and

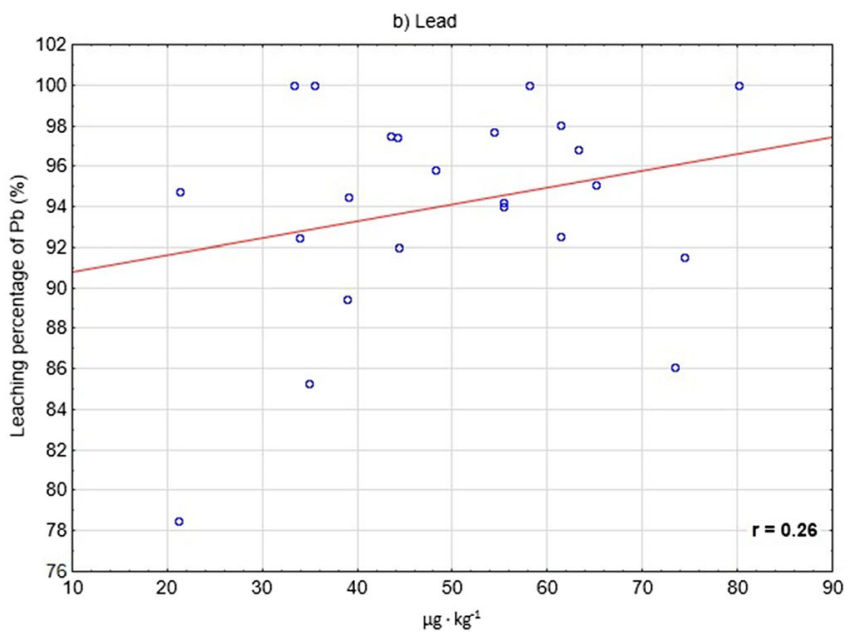

Fig. 1 Correlation between the content of $\mathrm{Cd}(\mathbf{a})$ and $\mathrm{Pb}(\mathbf{b})$ in coffee and the degree (\%) to which they pass into the infusion 
Table 5 Safety of coffee for consumption

\begin{tabular}{|c|c|c|}
\hline & $\mathrm{Cd}$ & $\mathrm{Pb}$ \\
\hline \multicolumn{3}{|c|}{ Pattern 1: drinking 1 cup of coffee a day } \\
\hline EWI, $\mu g^{1}$ & 0.156 & 1.968 \\
\hline$\% \mathrm{TWI}^{\mathrm{A}, \mathrm{B}}$ & 0.089 & \\
\hline$\% \mathrm{BMDL}_{01} \mathrm{~A}, \mathrm{C}$ & & 0.268 \\
\hline$\% \mathrm{BMDL}_{10}^{\mathrm{A}, \mathrm{D}}$ & & 0.639 \\
\hline $\mathrm{CD}^{2}$ & 0.022 & 0.281 \\
\hline $\mathrm{THQ}^{3}$ & 0.022 & 0.080 \\
\hline $\mathrm{HI}^{4}$ & 0.103 & \\
\hline \multicolumn{3}{|c|}{ Pattern 2: drinking 2 cups of coffee a day } \\
\hline EWI, $\mu \mathrm{g}^{1}$ & 0.312 & 3.936 \\
\hline$\% \mathrm{TWI}^{\mathrm{A}, \mathrm{B}}$ & 0.178 & \\
\hline$\% \mathrm{BMDL}_{01}^{\mathrm{A}, \mathrm{C}}$ & & 0.541 \\
\hline$\% \mathrm{BMDL}_{10} \mathrm{~A}, \mathrm{D}$ & & 1.278 \\
\hline $\mathrm{CDI}^{2}$ & 0.045 & 0.562 \\
\hline $\mathrm{THQ}^{3}$ & 0.045 & 0.161 \\
\hline $\mathrm{HI}^{4}$ & 0.205 & \\
\hline \multicolumn{3}{|c|}{ Pattern 3: drinking 3 cups of coffee a day } \\
\hline EWI, $\mu g^{1}$ & 0.468 & 5.715 \\
\hline$\% \mathrm{TWI}^{\mathrm{A}, \mathrm{B}}$ & 0.267 & \\
\hline$\%$ BMDL $01^{\mathrm{A}, \mathrm{C}}$ & & 0.778 \\
\hline$\% \mathrm{BMDL} 10^{\mathrm{A}, \mathrm{D}}$ & & 1.856 \\
\hline $\mathrm{CDI}^{2}$ & 0.067 & 0.816 \\
\hline $\mathrm{THQ}^{3}$ & 0.067 & 0.233 \\
\hline $\mathrm{HI}^{4}$ & 0.300 & \\
\hline
\end{tabular}

${ }^{1} E W I$, estimated weekly intake calculated on the basis of the mean weekly consumption of coffee infusions and mean level of $\mathrm{Cd}$ and $\mathrm{Pb}$

${ }^{2}$ Chronic daily intake calculated on the basis of the mean weekly consumption of coffee, mean level of $\mathrm{Cd}$ and $\mathrm{Pb}$ and exposure duration

${ }^{3}$ Target hazard quotient calculated on the basis of the chronic daily intake of $\mathrm{Cd}$ or $\mathrm{Pb}$

${ }^{4}$ Hazard index is the sum of THQ for $\mathrm{Cd}$ and $\mathrm{Pb}$

${ }^{\mathrm{A}}$ Mean body weight was assumed as $70 \mathrm{~kg}$

${ }^{\mathrm{B}}$ TWI, $2.5 \mu \mathrm{g}$ Cd per kg of body weight per week [16]

${ }^{\mathrm{C}}$ BMDL01, 10.5 $\mu \mathrm{g} \mathrm{Pb}$ per kg of body weight per week [17]

${ }^{\mathrm{D}}$ BMDL10, $4.4 \mu \mathrm{g} \mathrm{Pb}$ per kg of body weight per week [17]

$0.05 \mu \mathrm{g} \mathrm{Pb}$ per $1 \mathrm{~g}$. As $95.5 \% \mathrm{Cd}$ and $94 \% \mathrm{~Pb}$ passed into the infusion, the infusion contained on average $0.0037 \mu \mathrm{g} \mathrm{Cd}$ and ca. $0.047 \mu \mathrm{g} \mathrm{Pb}$ per $1 \mathrm{~g}$. Considering the consumption of coffee infusion (1, 2 or 3 cups a day), an adult Pole consumes less than $0.5 \mu \mathrm{g} \mathrm{Cd}$ and nearly $6 \mu \mathrm{g} \mathrm{Pb}$ per day. Nędzarek et al. [14] examined the content of, among other elements, $\mathrm{Pb}$ in infusions of coffee purchased in Poland $(n=4)$, Lebanon $(n$ $=1)$, Brazil $(n=3)$ and in Bosnia and Herzegovina $(n=3)$. These studies showed that infusions contained from 0.615 (Polish coffee) to $1.24 \mu \mathrm{g}$ (Bosnia and Herzegovina) Pb per $1 \mathrm{~g}$. According to those authors, in Poland, a person drinking $2.4 \mathrm{~kg}$ of coffee on an annual basis simultaneously consumes $1.48-2.43 \mathrm{mg} \mathrm{Pb}$, which is slightly more than $4 \mu \mathrm{g} \mathrm{Pb}$ per day, whereas, in Bosnia and Herzegovina, it is ca. $33 \mu \mathrm{g}$ Pb per day (12 mg per year).

Grembecka et al. [27] in 120 samples of different types of coffee, including 75 samples of ground coffee and 27 of instant coffee, found the presence of $\mathrm{Cd}$ and $\mathrm{Pb}$ in amounts lower than determinable using the applied method of analysis $\left(\mathrm{LOD} \mathrm{Cd}=0.003 \mathrm{mg} 100 \mathrm{~g}^{-1}\right.$, LOD Pb-0.01 mg $100 \mathrm{~g}^{-1}$ ). Gebretsadik et al. [28] in Ethiopian ground coffees found that

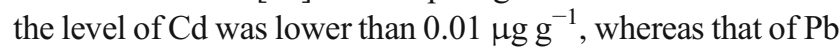

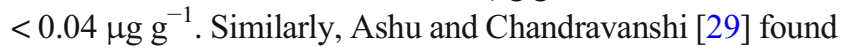
that both in dry grains and infusions of Ethiopian coffee $(n=$ 3), the level of $\mathrm{Cd}$ and $\mathrm{Pb}$ was lower than LOD. Studies in Brazil demonstrated that the level of $\mathrm{Cd}$ in roasted ground coffee $(n=15)$ was $<0.025 \mu \mathrm{g} \mathrm{g}^{-1}$, whereas the level of $\mathrm{Pb}$ ranged from 0.14 to $2.59 \mu \mathrm{g} \mathrm{g}^{-1}$ [15]. In as many as 8 samples, the level of $\mathrm{Pb}$ exceeded the maximum limit accepted by Brazilian legislation $0.5 \mu \mathrm{g} \mathrm{g}^{-1}$ [15]. According to other Brazilian studies [30], ground coffees contained 0.03$0.1 \mathrm{mg} \mathrm{Cd}$ and $0.025-1.58 \mathrm{mg} \mathrm{Pb}$ per $1 \mathrm{~kg}$. The same authors found that the coffees were not safe in terms of the content of $\mathrm{Pb}$; in $75 \%$ of 50 analysed samples, it contained more $\mathrm{Pb}$ than acceptable in Brazil, whereas, in $86 \%$ of samples, it exceeded the limit in the European Union $\left(0.2 \mu \mathrm{g} \mathrm{kg}^{-1}\right)$. In addition, da Silva et al. [30] found that the degree of extraction of Cd into the infusion is $26 \%$ and that of $\mathrm{Pb}$ is less than $47 \%$; the values were considerably lower than measured by the present author. Instant coffees drunk in India contained $0.001-0.03 \mu \mathrm{g} \mathrm{g}^{-1} \mathrm{Cd}$ and $0.02-0.2 \mu \mathrm{g} \mathrm{g}^{-1} \mathrm{~Pb}$ [31]. Studies carried out in Saudi Arabia showed that dry coffee contained $0.053 \mu \mathrm{g} \mathrm{Pb} \mathrm{g}^{-1}$ [32]. In turn, Santos et al. [33] found that in coffee grains, the average content of $\mathrm{Cd}<0.1 \mu \mathrm{g} \mathrm{g}^{-1}$, whereas that of $\mathrm{Pb}$ $<2.6 \mu \mathrm{g} \mathrm{g}^{-1}$. Turkish studies showed that green coffee grains contained on average $0.005 \mu \mathrm{g} \mathrm{g}^{-1} \mathrm{Cd}\left(0.003-0.006 \mu \mathrm{g} \mathrm{g}^{-1}\right)$ and $0.12 \mu \mathrm{g} \mathrm{g}^{-1} \mathrm{~Pb}\left(0.06-0.3 \mu \mathrm{g} \mathrm{g}^{-1}\right)$ [34]. Those authors recount that up to $84 \%$ of $\mathrm{Cd}$ and up to $82.6 \%$ of $\mathrm{Pb}$ pass into the infusion, which is dependent on the coffee brewing method only (Turkish method - cooking - leaches more minerals, including toxic elements - except for $\mathrm{Pb}$, than pouring with boiling water as practised in Poland), but it is not dependent on the type of coffee. Studies by Anderson et al. [35] also showed that $\mathrm{Pb}$ can be leached from vessels into the ground coffee infusion - the highest amount of $\mathrm{Pb}$ passes from ceramic cups.

In the presented studies, the values of CDI, THQ and HI indicators for all the assumed patterns were lower than 1 , which means that the risk of developing diseases connected with chronic exposure to $\mathrm{Cd}$ and $\mathrm{Pb}$ consumed with coffee must be evaluated as very low. Coffee drinking safety is also confirmed by the degree of coverage of the tolerable intake level of $\mathrm{Cd}$ and $\mathrm{Pb}$ recommended by EFSA $[16,17]$. According to the studies of the present author, drinking 3 cups of coffee a day contributes to supplying these metals in the amount of less than $0.3 \%$ TWI (Cd) and less than $2 \%$ BMDL 
$(\mathrm{Pb})$. According to Şemen et al. [34], drinking 2 cups of coffee a day contributes to $\mathrm{Cd}$ intake amounting to $0.01-0.06 \%$ PTWI and Pb intake amounting to $0.03-0.38 \%$ PTWI, depending on the type of coffee and content of toxic metals. Suseela et al. [31] found that drinking instant coffee contributes to intake of $\mathrm{Cd}$ amounting to $1.1 \%$ and that of $\mathrm{Pb}$ amounting to $0.7 \%$ of the acceptable limit in India. Pigozzi et al. [15] recount that $1 \mathrm{cup}(50 \mathrm{ml})$ of Brazilian ground coffee infusion contains maximum $2.835 \mu \mathrm{g} \mathrm{Pb}$, which accounts for 0.21 to $4.54 \%$ of the acceptable limit (that is $25 \mu \mathrm{g} \mathrm{kg}^{-1}$ of body weight), while the content of $\mathrm{Cd}$ in those coffees was lower than LOD.

To sum up, the content of $\mathrm{Cd}$ and $\mathrm{Pb}$ in the analysed coffee infusions was very low. However, it must be remembered that no threshold limits for toxic metal consumption exist because these metals accumulate in the body for a long time; in the case of $\mathrm{Cd}$ and $\mathrm{Pb}$, it is even 30 years [18], whereas their largest amounts accumulate in organs in charge of detoxicating processes (liver and kidneys) and in the brain [19, 36], leading to their damage and dysfunction. Nędzarek et al. [14] mention the level of $\mathrm{Pb}$ in coffee; despite it was low in their studies, those authors suggest that the content of $\mathrm{Pb}$ in coffee should be monitored regularly because it is higher than the content of $\mathrm{Cd}$ and can accumulate in tissues. Studies involving rats showed that during complex exposure $(\mathrm{Cd}+\mathrm{Pb})$, $\mathrm{Pb}$ accumulates in the organs to a higher degree than $\mathrm{Cd}(0.6 \%$ vs $0.48 \%$ in adults and $0.5 \%$ vs $0.7 \%$ in a younger population) $[19,36]$. Lead is absorbed to a higher extent by the gastrointestinal tract than $\mathrm{Cd}$ after oral intake (10-50\%, 1-8\%) [37, $38]$. In the presented study of this authors, an alarming signal is $\mathrm{CDI}_{\mathrm{Pb}}$ close to 1 . It must be taken into account that some authors found that the $\mathrm{Pb}$ level was higher than acceptable in $75 \%$ of the analysed samples $[15,30]$. The studies presented here also showed a low $(r=0.26)$ but still, a positive correlation between the content of $\mathrm{Pb}$ in coffee and the degree (\%) to which $\mathrm{Pb}$ passed into the infusion. This problem should be thoroughly investigated.

\section{Conclusions}

The content of $\mathrm{Cd}$ and $\mathrm{Pb}$ in the analysed coffee infusions was very low, so drinking coffee does not pose a risk for consumers in terms of the content of these metals. However, it must be remembered that no threshold limits for toxic metal consumption exist because these metals accumulate in the body for a long time; in the case of $\mathrm{Cd}$ and $\mathrm{Pb}$, it is even 30 years.

\section{Compliance with ethical standards}

Conflict of interest The authors declare that they have no conflicts of interest.
Open Access This article is licensed under a Creative Commons Attribution 4.0 International License, which permits use, sharing, adaptation, distribution and reproduction in any medium or format, as long as you give appropriate credit to the original author(s) and the source, provide a link to the Creative Commons licence, and indicate if changes were made. The images or other third party material in this article are included in the article's Creative Commons licence, unless indicated otherwise in a credit line to the material. If material is not included in the article's Creative Commons licence and your intended use is not permitted by statutory regulation or exceeds the permitted use, you will need to obtain permission directly from the copyright holder. To view a copy of this licence, visit http://creativecommons.org/licenses/by/4.0/.

\section{References}

1. Martini D, Del Bo' C, Tassotti M, Riso P, Del Rio D, Brighenti F, Porrini M (2016) Coffee consumption and oxidative stress: a review of human intervention studies. Molecules 21:979. https://doi.org/ $10.3390 /$ molecules 21080979

2. Nkondjock A (2009) Coffee consumption and the risk of cancer: an overview. Cancer Lett 277:121-125. https://doi.org/10.1016/j. canlet.2008.08.022

3. Cao S, Liu L, Yin X, Wang Y, Liu J, Lu Z (2014) Coffee consumption and risk of prostate cancer: a meta-analysis of prospective cohort studies. Carcinogenesis 35:256-261. https://doi.org/10. 1093/carcin/bgt482

4. Huxley R, Lee CM, Barzi F, Timmermeister L, Czernichow S, Perkovic V, Grobbee DE, Batty D, Woodward M (2009) Coffee, decaffeinated coffee, and tea consumption in relation to incident type 2 diabetes mellitus: a systematic review with meta-analysis. Arch Intern Med 169:2053-2063. https://doi.org/10.1001/ archinternmed.2009.439

5. Sääksjärvi K, Knekt P, Rissanen H, Laaksonen MA, Reunanen A, Männistö S (2008) Prospective study of coffee consumption and risk of Parkinson's disease. Eur J Clin Nutr 62:908-915. https://doi. org/10.1038/sj.ejcn. 1602788

6. Chudy S (2014) Development of coffee market and changes in coffee consumption among Poles. J Agribus Rural Dev 34:41-51

7. Özen AE, Bibiloni Mdel M, Pons A, Tur JA (2014) Consumption of functional foods in Europe; a systematic review. Nutr Hosp 29: 470-478. https://doi.org/10.3305/nh.2014.29.3.7148

8. Statistical Yearbook of the Republic of Poland (2018) Statistical Publishing Establishment, Warsaw, Poland.

9. Bartkowicz J (2015) The selected behaviours of consumers in the market for natural coffee. Handel Wewn 355:45-57

10. Kwiatkowska K, Winiarska-Mieczan A, Kwiecień M, Klebaniuk R, Krusiński R, Rusinek-Prystupa E, Sembratowicz I, Kamińska E, Danek-Majewska A, Cholewińska E (2017) Analysis of coffee consumption among primary school teachers. Probl Hig Epidemiol 98: 285-289

11. EFSA (2015) Scientific opinion on the safety of caffeine. EFSA J 13(5):4102. https://doi.org/10.2903/j.efsa.2015.4102

12. Gökcen BB, Şanlier N (2017) Coffee consumption and disease correlations. Crit Rev Food Sci Nutr 59:336-348. https://doi.org/ 10.1080/10408398.2017.1369391

13. Poole R, Kennedy OJ, Roderick P, Fallowfield JA, Hayes PC, Parkes J (2017) Coffee consumption and health: umbrella review of meta-analyses of multiple health outcomes. BMJ 359:j5024. https://doi.org/10.1136/bmj.j5024

14. Nędzarek A, Tórz A, Karakiewicz B, Clark JS, Laszczyńska M, Kaleta A, Adler G (2013) Concentrations of heavy metals (Mn, 
$\mathrm{Co}, \mathrm{Ni}, \mathrm{Cr}, \mathrm{Ag}, \mathrm{Pb}$ ) in coffee. Acta Biochim Pol 60:623-627. https://doi.org/10.18388/abp.2013_2031

15. Pigozzi MT, Passos FR, Mendes FQ (2018) Quality of commercial coffees: heavy metal and ash contents. J Food Qual 2018:59084635908467. https://doi.org/10.1155/2018/5908463

16. EFSA (2012) Cadmium dietary exposure in the European population. EFSA J 10(1):2551. https://doi.org/10.2903/j.efsa.2012.2551

17. EFSA (2012) Lead dietary exposure in the European population. EFSA J 10(7):2831. https://doi.org/10.2903/j.efsa.2012.2831

18. Winiarska-Mieczan A, Grela ER (2017) Content of cadmium and lead in raw, fried and baked commercial frozen fishery products consumed in Poland. J Sci Food Agric 97:2969-2974. https://doi. org/10.1002/jsfa.8136

19. Winiarska-Mieczan A, Kwiecień M (2016) The effect of exposure to $\mathrm{Cd}$ and $\mathrm{Pb}$ in the form of a drinking water or feed on the accumulation and distribution of these metals in the organs of growing Wistar rats. Biol Trace Elem Res 169:230-236. https://doi.org/10. 1007/s12011-015-0414-4

20. Winiarska-Mieczan A (2014) Cadmium, lead, copper and zinc in breast milk in Poland. Biol Trace Elem Res 157:36-44. https://doi. org/10.1007/s12011-013-9870-x

21. Winiarska-Mieczan A, Kwiatkowska K, Kwiecień M, Baranowska-Wójcik E, Wójcik G, Krusiński R (2019) Analysis of the intake of sodium with cereal products by the population of Poland. Food Addit Contam Part A 36:884-892. https://doi.org/10. 1080/19440049.2019.1605209

22. Winiarska-Mieczan A, Florek M, Kwiecień M, Kwiatkowska K, Krusiński R (2018) Cadmium and lead content in chosen commercial fishery products consumed in Poland and risk estimations on fish consumption. Biol Trace Elem Res 182:371-380. https://doi. org/10.1007/s12011-017-1104-1

23. Sultana MS, Rana S, Yamazaki S, Aono T, Yoshida S (2017) Health risk assessment for carcinogenic and noncarcinogenic heavy metal exposures from vegetables and fruits of Bangladesh. Cog Environ Sci 3:1291107. https://doi.org/10.1080/23311843.2017. 1291107

24. Issa AB, Yasin K, Loutfy N, Ahmed MT (2018) Risk assessment of heavy metals associated with food consumption in Egypt: a pilot study. J Clin Exp Toxicol 2:15-24

25. Song D, Zhuang D, Jiang D, Fu J, Wang Q (2015) Integrated health risk assessment of heavy metals in Suxian County, South China. Int J Environ Res Public Health 12:7100-7117. https://doi.org/10. 3390/ijerph120707100

26. IRIS, Integrated Risk Information System (2015) U.S. Environmental Protection Agency. Chemical Assessment Summary. National Center for Environmental Assessment. https://cfpub.epa.gov/ncea/iris/iris_documents/documents/subst/ 0141_summary.pdf (26.04.2019)

27. Grembecka M, Malinowska E, Szefer P (2007) Differentiation of market coffee and its infusions in view of their mineral composition. Sci Total Environ 383:59-69. https://doi.org/10. 1016/j.scitotenv.2007.04.031

28. Gebretsadik TA, Berhanu T, Kefarge B (2015) Levels of selected essential and nonessential metals in roasted coffee beans of Yirgacheffe and Sidama, Ethiopia. Am J Environ Prot 4:188-192. https://doi.org/10.11648/j.ajep.20150404.13

29. Ashu R, Chandravanshi BS (2011) Concentration levels of metals in commercially available Ethiopian roasted coffee powders and their infusions. Bull Chem Soc Ethiop 25:11-24. https://doi.org/ 10.4314/bcse.v25i1.63356

30. da Silva SA, Mendes FQ, Reis MR, Passos FR, de Carvalho AMX, de Oliveira Rocha KR, Pinto FG (2017) Determination of heavy metals in the roasted and ground coffee beans and brew. Afr J Agric Res 12:221-228. https://doi.org/10.5897/AJAR2016.11832

31. Suseela B, Bhalke S, Kumar AV, Tripathi RM, Sastry VN (2001) Daily intake of trace metals through coffee consumption in India. Food Addit Contam 18:115-120. https://doi.org/10.1080/ 02652030010008814

32. Al Othman ZA (2010) Lead contamination in selected foods from Riyadh city market and estimation of the daily intake. Molecules 15:7482-7497. https://doi.org/10.3390/molecules 15107482

33. Santos WPC, Hatje V, Lima LN, Trignano SV, Barros F, Castro JT, Korn MGA (2008) Evaluation of sample preparation (grinding and sieving) of bivalves, coffee and cowpea beans for multi-element analysis. Microchem J 89:123-130. https://doi.org/10.1016/j. microc.2008.01.003

34. Șemen S, Mercan S, Yayla M, Açıkkol M (2017) Elemental composition of green coffee and its contribution to dietary intake. Food Chem 215:92-100. https://doi.org/10.1016/j.foodchem.2016.07. 176

35. Anderson GL, Garnick L, Fung MS, Gaffney SH (2017) A pilot study to assess lead exposure from routine consumption of coffee and tea from ceramic mugs: comparison to California Safe Harbor Levels. Int J Food Contam 4:4. https://doi.org/10.1186/s40550017-0049-7

36. Winiarska-Mieczan A (2014) Cumulative rate and distribution of $\mathrm{Cd}$ and $\mathrm{Pb}$ in the organs of adult male Wistar rats during oral exposure. Environ Toxicol Pharmacol 38:751-760. https://doi. org/10.1016/j.etap.2014.08.016

37. Ohta H, Yamauchi Y, Nakakita M, Tanaka H, Asami S, Seki Y, Yoshikawa H (2003) Relationship between renal dysfunction and bone metabolism disorder in male rats after long-term oral quantitative cadmium administration. Ind Health 38:339-355

38. Järup L (2003) Hazards of heavy metal contamination. Br Med Bull 68:167-182

Publisher's Note Springer Nature remains neutral with regard to jurisdictional claims in published maps and institutional affiliations. 